\title{
No K/T boundary at Anjar, Gujarat, India: Evidence from magnetic susceptibility and carbon isotopes
}

\author{
H J Hansen*, D M MohabeY** and P TofT* \\ * Geological Institute, Oster Voldgade 10, DK-1350, Denmark \\ ** Geological Survey of India, Seminary Hills, Nagpur 440 006, India
}

The paper describes the variation pattern of magnetic susceptibility of Lameta sediments and isotopic variation of organic ${ }^{13} \mathrm{C}$ from Chui Hill, Bergi, Kholdoda, Pisdura and Girad. The susceptibility pattern and a negative carbon isotopic anomaly allows fixation of the $\mathrm{K} / \mathrm{T}$ boundary at these localities and they differ in these aspects from the inter-trappean sediments at Anjar.

Paleomagnetic measurements of the Anjar sediment and the overlying basalt flow demonstrate reversed polarity. The Lameta sediments with dinosaur nests at Kheda and the overlying intertrappean sediments are of normal polarity.

The clay layers at Anjar, associated closely with Ir-enrichments, are strongly leached, rhyolitic bentonites containing low-quartz paramorphs after high-quartz with glass inclusions.

It is concluded, that the inter-trappean lake deposits at Anjar were deposited in the early part of magnetochron $29 \mathrm{R}$ and are unrelated to the $\mathrm{K} / \mathrm{T}$ boundary.

\section{Introduction}

Since the find of three horizons enriched in iridium in the inter-trappean lake sediments at Anjar, these sediments have repeatedly been indicated to contain the $\mathrm{K} / \mathrm{T}$ boundary (Bhandari et al 1995a,b; 1996). As the sediments are stratigraphically placed between three underlying basalt flows of normal magnetic polarity (Bhandari et al 1995b; Courtillot et al 2000) and overlain by four flows of which the three uppermost are of reversed magnetic polarity the possibility of the presence of a $\mathrm{K} / \mathrm{T}$ boundary cannot be ruled out.

On the other hand, the find of dinosaur eggshell fragments and other fossils apparently not revorked, occurring above the uppermost Irenrichment horizon speaks against a $\mathrm{K} / \mathrm{T}$ boundary (unless the dinosaurs persisted into Paleocene time) (Bajpai 1999; Bajpai and Prasad 2000). Radiometric dating of the flows (Venkatesan et al 1996, Courtillot et al 2000) does not contradict a placement of the sediments in magnetochron 29R.

The indication of the presence of a K/T boundary rests solely on the existence of three iridiumenriched layers. It appears to be a general misconception that an iridium-enrichment is part of the definition of the $\mathrm{K} / \mathrm{T}$ boundary as fixed in the boundary stratotype section at El Kef, Tunisia. The boundary is a biostratigraphic boundary and the "golden spike" is placed at the extinction level of Upper Cretaceous planktonic foraminifera and the temporary and permanent disappearance of many coccolith species. In the El Kef section, the boundary is coinciding with an Ir-enrichment, while a second Ir-enrichment reported by Kuslys and Krähenbühl (1983) is found slightly higher in the same section.

Although an enrichment of Ir occurs at the extinction level in many marine sequences (in India at the Megalaya locality, Bhandari et al 1987, 1994) it is not always so, and the occurrence of Ir cannot be taken as a $\mathrm{K} / \mathrm{T}$ boundary criterion. Four Ir-enrichment horizons occur in an Upper Paleocene marine sequence in Slovenia (Dolenec et al 1998), one occurs at the P1b/P1c biostratigraphic boundary in Negev, Israel, where no Ir-enrichment exists at the $\mathrm{K} / \mathrm{T}$ boundary (Hansen, unpublished) and one Ir-enrichment occurs in a Paleocene volcanic ashbed on Nugssuaq, Central Westgreenland (Margolis et al 1991). This demonstrates, that Irenrichments are not unique to the $\mathrm{K} / \mathrm{T}$ boundary and they cannot per se be used as a stratigraphic indicator in either marine or terrestrial deposits.

Keywords. Iridium; rhyolites; paleomagnetics; Deccan; Lameta.

Proc. Indian Acad. Sci. (Earth Planet. Sci.), 110, No. 2, June 2001, pp. 133-142

(C) Printed in India. 
At Anjar, the three Ir-enrichment horizons are each found a short distance below a clay bed. The present paper reports the magnetic susceptibility and organic carbon isotope variation of the sediments. It also deals with the results of different investigations of the two uppermost clay beds as well as the magnetic polarity of the Ir-bearing inter-trappean sediments and the overlying basalt flow along with results of studies of other Indian $\mathrm{K} / \mathrm{T}$ boundary sections.

\section{Materials and methods}

Oriented blocks were collected in the field and 1 inch diameter plugs were later drilled in the laboratory. The precision of the orientation is therefore not as good as it could have been had the plugs been drilled in the field. The plugs were submitted to thermal demagnetization up to $790^{\circ} \mathrm{C}$ in a Schonstedt TSD-1 thermal demagnitizer and afterwards measured in a JR-5A spinner magnetometer (Geofyzika, Brno).

Samples of the clay beds were crushed using an agat mortar. Main element analysis was made by the chemical laboratory of the Geological Survey of Denmark and Greenland (GEUS) and values are reported as oxides; a few trace elements were also obtained. The sediments of Anjar intertrappeans were collected in 100-150 gram samples with a stratigraphic equidistance of $10 \mathrm{~cm}$ and at a later occasion the upper part was re-sampled with $5 \mathrm{~cm}$ equidistance in order to confirm the pattern found in the first series collected. The samples were crushed to $0.5 \mathrm{~cm}$ pieces, placed in medical plastic pill-trays and measured for their magnetic susceptibility using a Kappabridge KLY-2 instrument (Geofyzika, Brno). The values are reported in SI units per 20 g dry sample.

Samples for organic carbon isotopes were dissolved in $\mathrm{HCl}$ and $\mathrm{HF}$ following standard procedures. They were measured in the Stable Isotope Laboratory, Geological Institute, Univ. Copenhagen.

\section{Observations}

Both the Anjar inter-trappean sediment and the overlying basalt flow no. IV showed a magnetic behaviour, where declinations and inclinations suggest overprinted fields that were removed at $700^{\circ} \mathrm{C}$ after which a reversed declination and a stable inclination of around 60 degrees appeared (figure 1). This leads us to suggest that overlying the lowermost three flows of normal magnetic polarity, the inter-trappean sediment and the topmost four flows are of reversed polarity. We interpret the pattern as
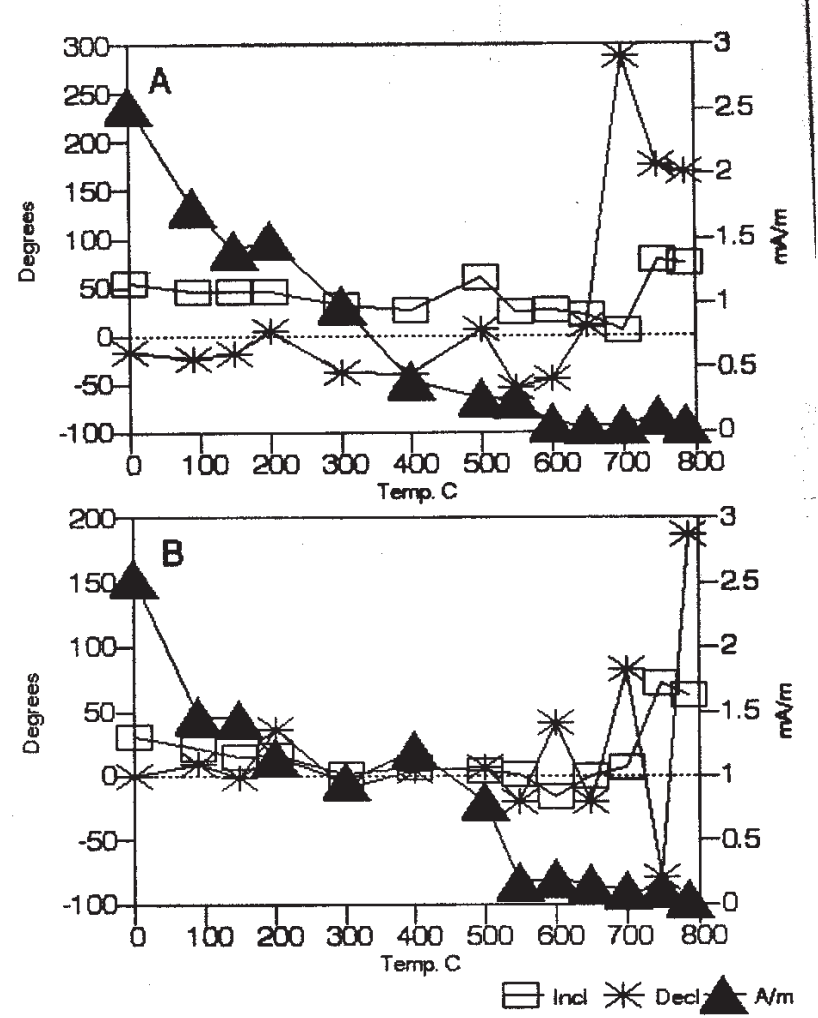

Figure 1. Behaviour of vector length, inclination and declination of paleomagnetic field during demagnetisation of $\mathbf{A}$ : Anjar Deccan Basalt Flow IV; B: Anjar Ir-bearing lake sediment.

representing the change from magnetochron $30 \mathrm{~N}$ to $29 \mathrm{R}$ at the contact between flow III and the intertrappean sediment. If it should represent the shift from $29 \mathrm{~N}$ to $28 \mathrm{R}$, it would involve dinosaurs surviving into Paleocene time.

The Lameta sediments exposed at Chui Hill, Kholdoda, Pisdura, Girad and Bergi were sampled and measured for their magnetic susceptibility (figure 2). Samples for magnetic susceptibility were later processed for organic carbon isotopes ensuring a perfect stratigraphic match between the two. The results are shown in figures 3-7 where the magnetic susceptibility is plotted against stratigraphic height along with the non-carbonate carbon isotopes. All sections showed a persistent pattern (even the very short section at Bergi) and allows correlation.

The section at Girad differs from the other sections by having flows of basalt interspaced in the Lameta sediments. We measured the magnetic polarity of flow 1 (the lowermost), of flow 2 and flow 4 (the topmost). Flow 1 showed a recent overprint which by TD was removed at $300^{\circ} \mathrm{C}$. Between 300 and 500 we found a reverse declination and inclination while the vector became unstable at higher temperatures (figure 8). We interpret the magne- 


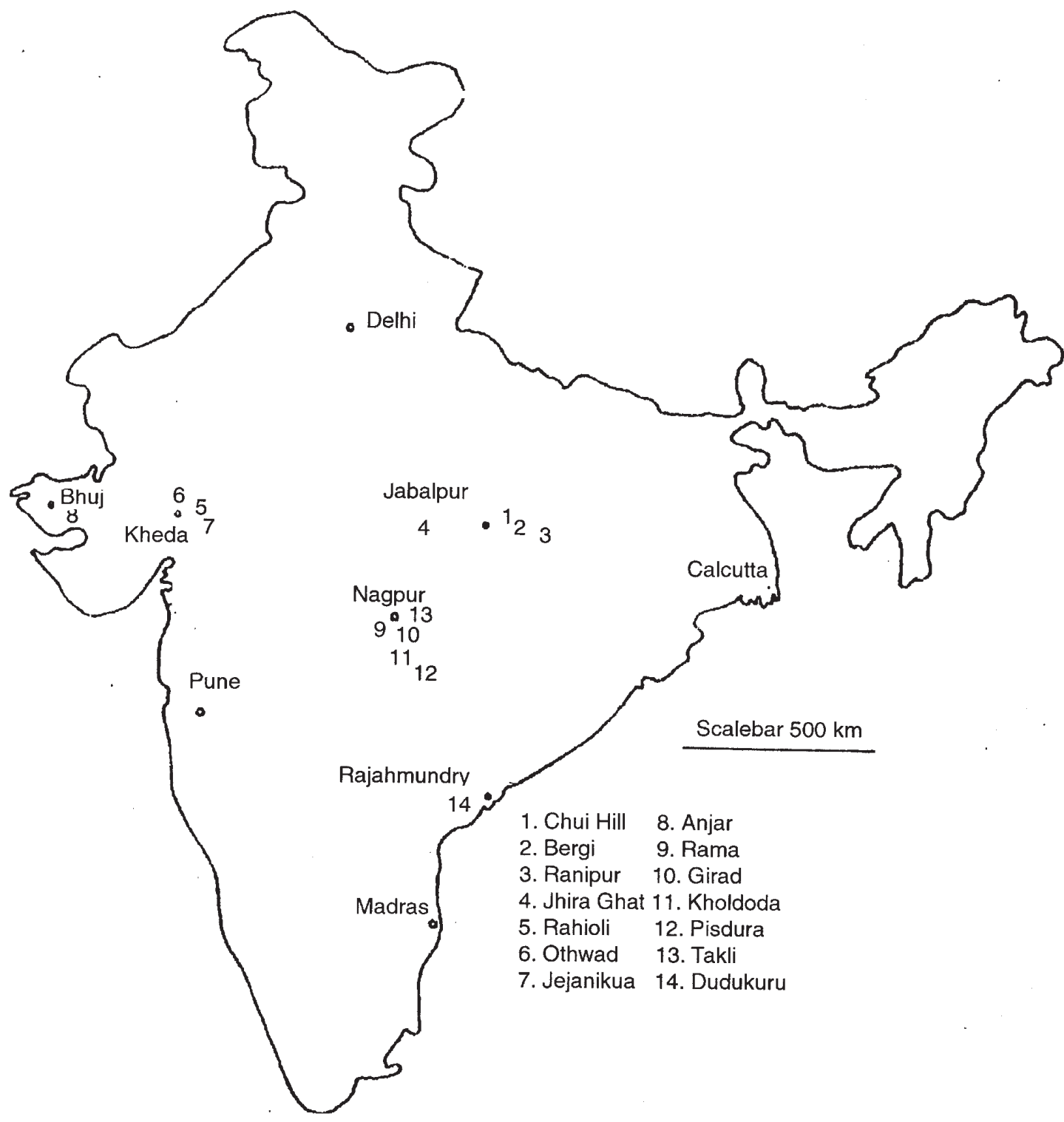

Figure 2. Map showing the geographic position of Indian localities mentioned in the text.

tization as reversed. The topmost flow a Girad showed a stable reverse vector to $350^{\circ} \mathrm{C}$ after which it became unstable. We regard flow 4 as belonging to a reversed period. Flow 2 showed inconsistent magnetic behaviour.

The magnetic susceptibility and carbon isotopic pattern of the Upper Maastrichtian marine series at El Kef and the terrestrial series at North Horn, Utah (Hansen et al 1996) allows high resolution correlation with the Indian sections. On the basis of the magnetic susceptibility patterns we identify the $\mathrm{K} / \mathrm{T}$ boundary at the top of cycle zero of Hansen et al $(1993,1996)$ in the Indian sections. The pattern of both magnetic susceptibility and carbon isotopes as registered in the Lameta sections are, however, in no way comparable to the pattern found in the Anjar inter-trappean (figure 9).

The course and magnitude of the negative carbon isotopic anomaly is rather uniform from place to place with the exception of Chui Hill, where it ranges from almost $-21 \%$ PDB to -27.5 and thereby is one of the strongest ever recorded. It is stronger than in the other sections. The other Lameta sections demonstrate a shorter duration of the anomaly relative to the susceptibility pattern followed by a return to less negative values. At Chui Hill no return to previous, less negative values is observed. The Chui Hill section also differs from the other sections by the absence (on top of cycle zero) of fine-grained red and green, structureless sediments. 

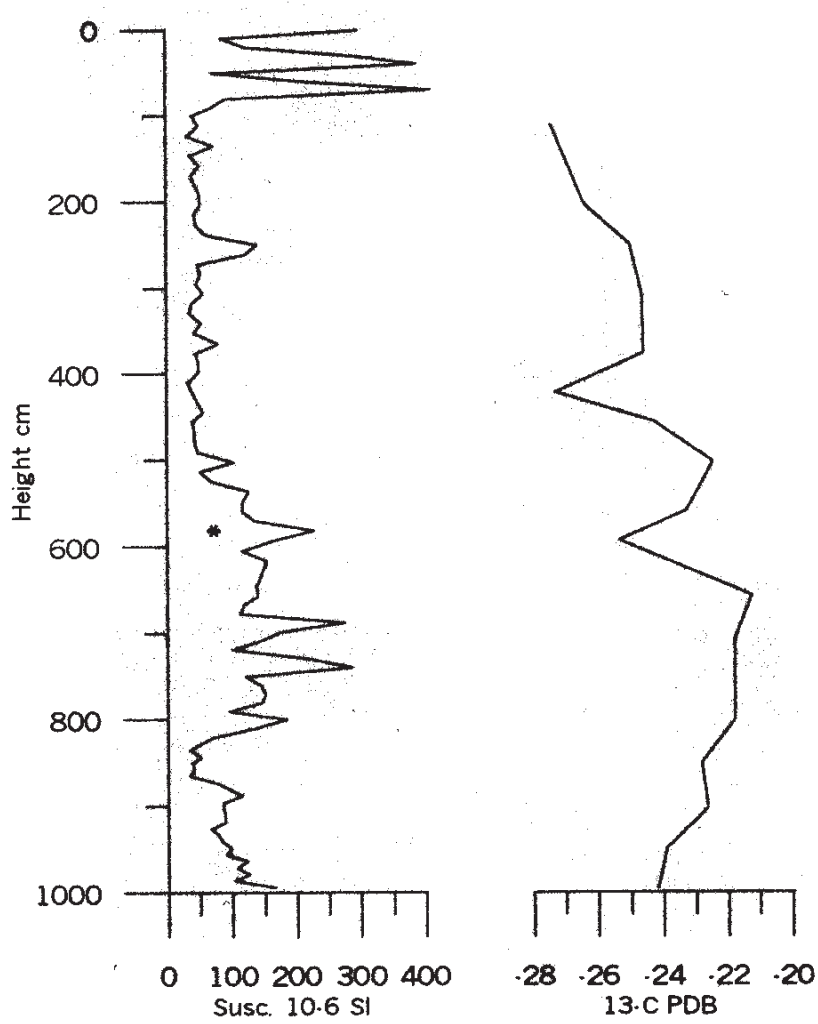

Figure 3. Stratigraphic plot of magnetic susceptiblity and organic carbon isotopes at the Chui Hill Lameta section, Jabalpur. An asterisk marks the $\mathrm{K} / \mathrm{T}$ boundary level in figures $3-7$.

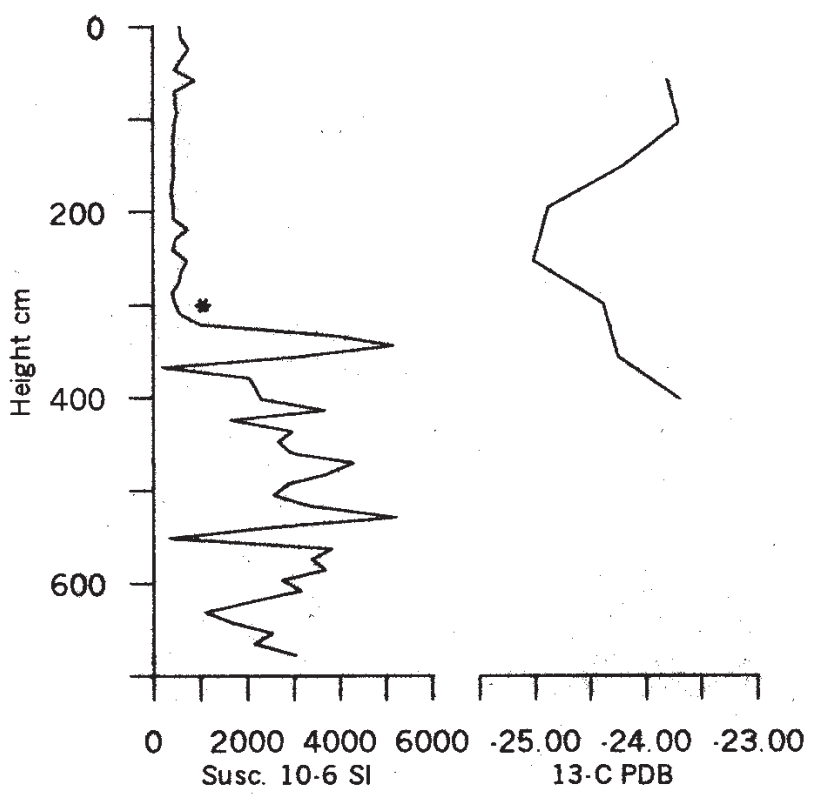

Figure 4. Stratigraphic plot of magnetic susceptiblity and organic carbon isotopes at the Kholdoda Lameta section.

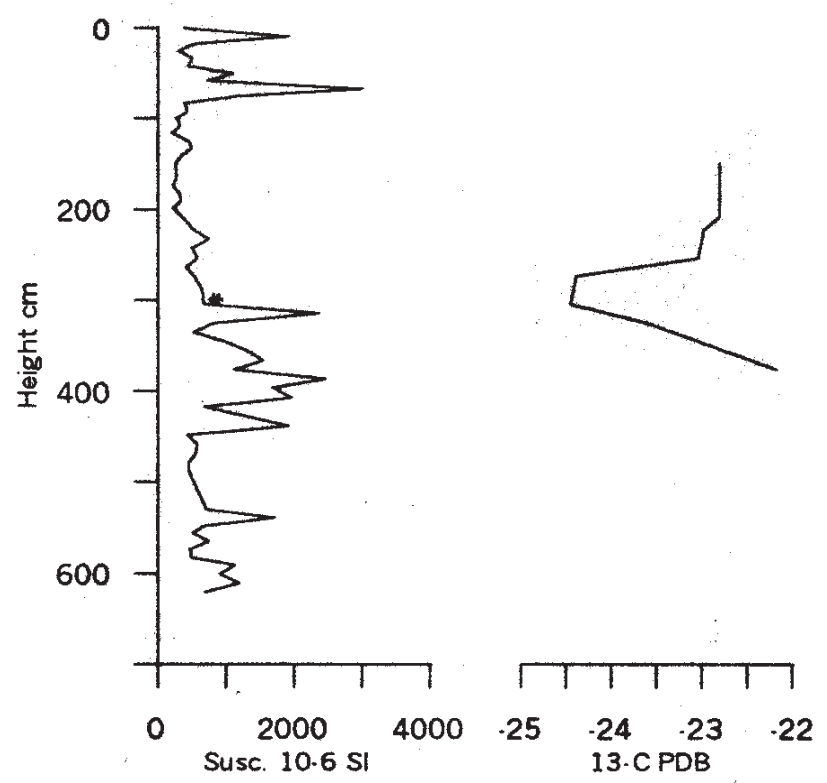

Figure 5. Stratigraphic plot of magnetic susceptibility and organic carbon isotopes at the Pisdura Lameta section.

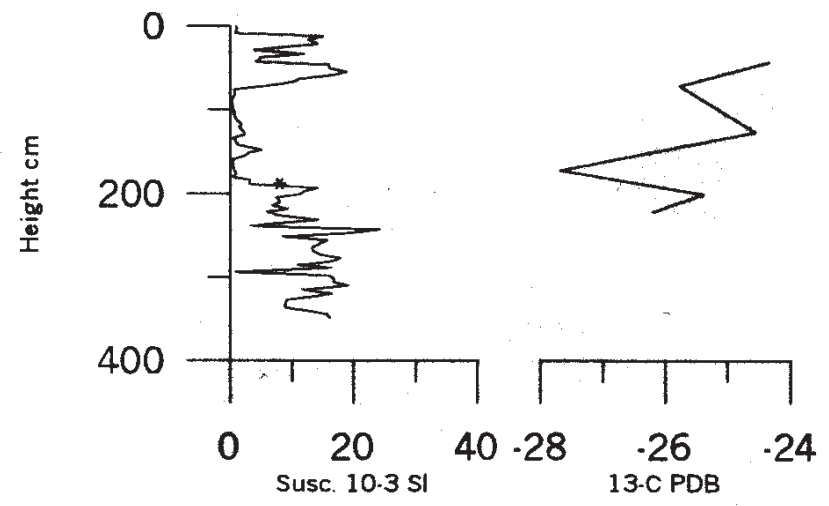

Figure 6. Stratigraphic plot of magnetic susceptibility and organic carbon isotopes at the Girad Lameta section.

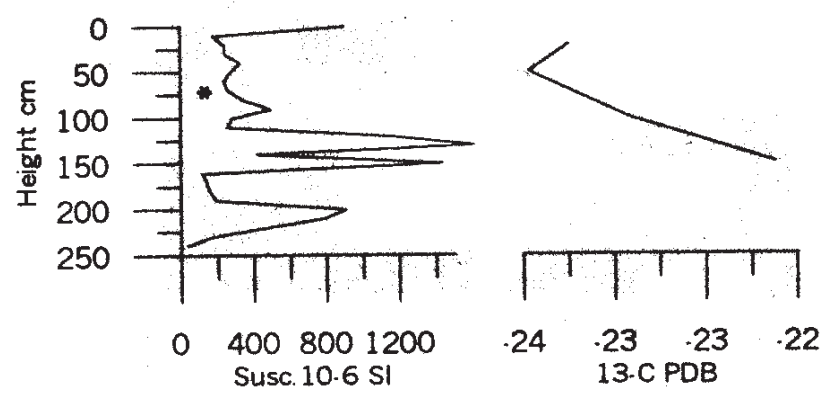

Figure 7. Stratigraphic plot of magnetic susceptibility and organic carbon isotopes at the Bergi Canal Lameta section. 


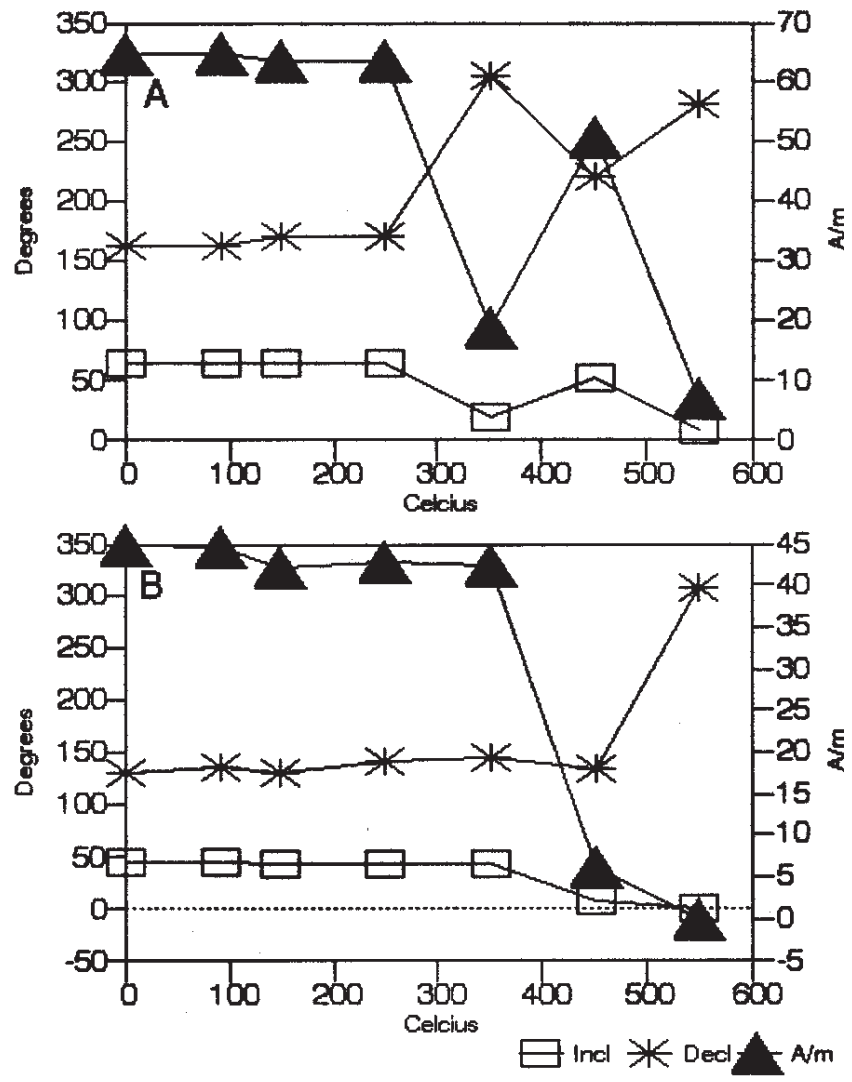

Figure 8. Behaviour of vector length, inclination and declination of paleomagnetic field during demagnetisation of $\mathbf{A}$ : Girad flow 1. B: Girad flow 4.

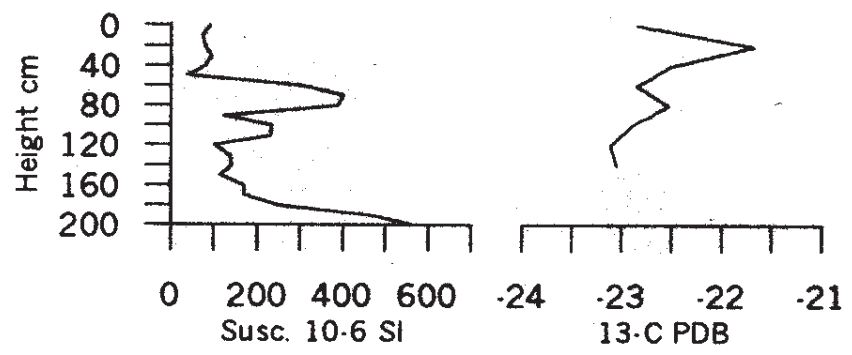

Figure 9. Stratigraphic plot of magnetic susceptibility and organic carbon isotopes from Anjar Ir-bearing lake sediments.

In the magnetic susceptibility pattern we commonly find one or two peaks directly below the overlying basalt flow i.e. in the red material. We interpret these peaks as caused by heat conversion of goethite or associated minerals into hematite (Brown 1980) and therefore of no value as stratigraphic markers and unrelated to the sedimentary rhythms.

Shortly after the $\mathrm{K} / \mathrm{T}$ boundary in terrestrial sections in China, France, USA and Canada we have found aeolian sediments. We suggest that the topmost fine-grained, sediments occurring under the basalts are of aeolian origin. Grainsize analysis of the topmost sediments from Pisdura, Kholdoda

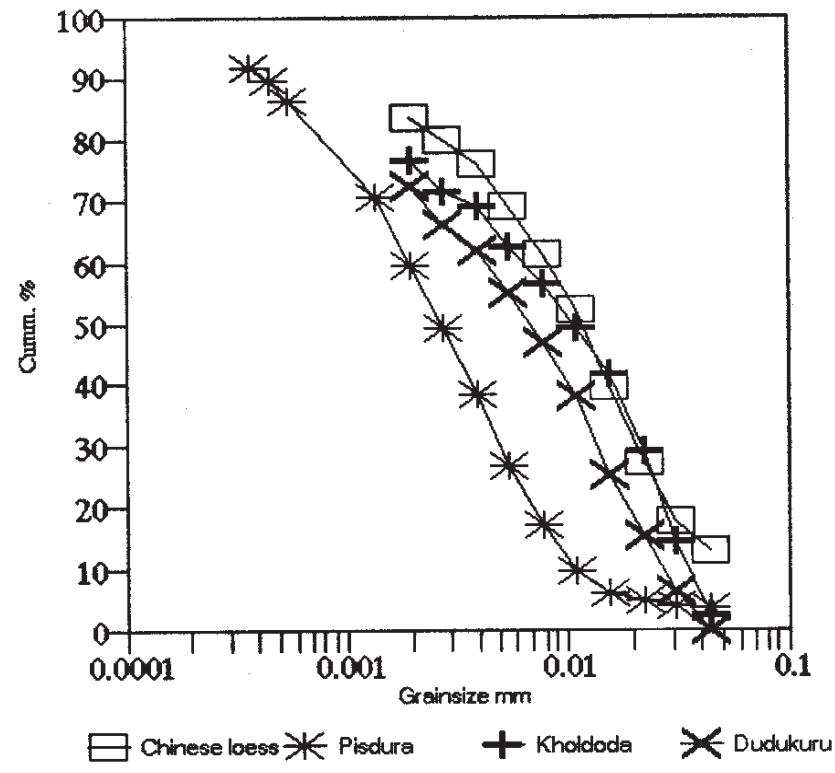

Figure 10. Grain size curves of Chinese Holocene loess and loess-like sediments from Pisdura, Duddukuru and Kholdoda.

and Duddukuru compare well with that of Chinese Holocene loess (figure 10). An aeolian origin of these deposits also explains the return to less negative carbon isotopic values which could well be due to a content of wind-blown older carbon. The sediments are without bedding and show only rhizomes (plant root systems) which is in good agreement with the appearance of loess-like sediments.

At Kheda, carbonate-cemented sandstones contain numerous dinosaur nests (Mohabey 1984, 2000). The nest-bearing sediments were sampled for paleomagnetics and yielded a clear and stable normal polarity (figure 11). In order to establish the magnetic polarity of the overlying basalts at Kheda we sampled at Jejanikua the lowermost basalt flow and an overlying inter-trappean sediment. The magnetic vector from the basalt showed a random behaviour and was discarded. By contrast, the inter-trappean sediment demonstrated a stable normal polarity vector in the interval from 0 to $650^{\circ} \mathrm{C}$ above which the behaviour became erratic. We regard the inter-trappean sediment at Jejanikua as being of normal polarity. Additional sampling at Othwad of two basalt flows and an inter-trappean sediment did not yield intelligible results. Samples of limestone from the Lametaghat locality and from Kholdoda were found to be of reversed polarity. This demonstrates, that the Lameta sediments are possibly time-transgressive, with the older sediments deposited to the NW and younger sediments to the $\mathrm{S}$.

Samples of the two youngest clay layers each found shortly above an iridium bearing horizon in 

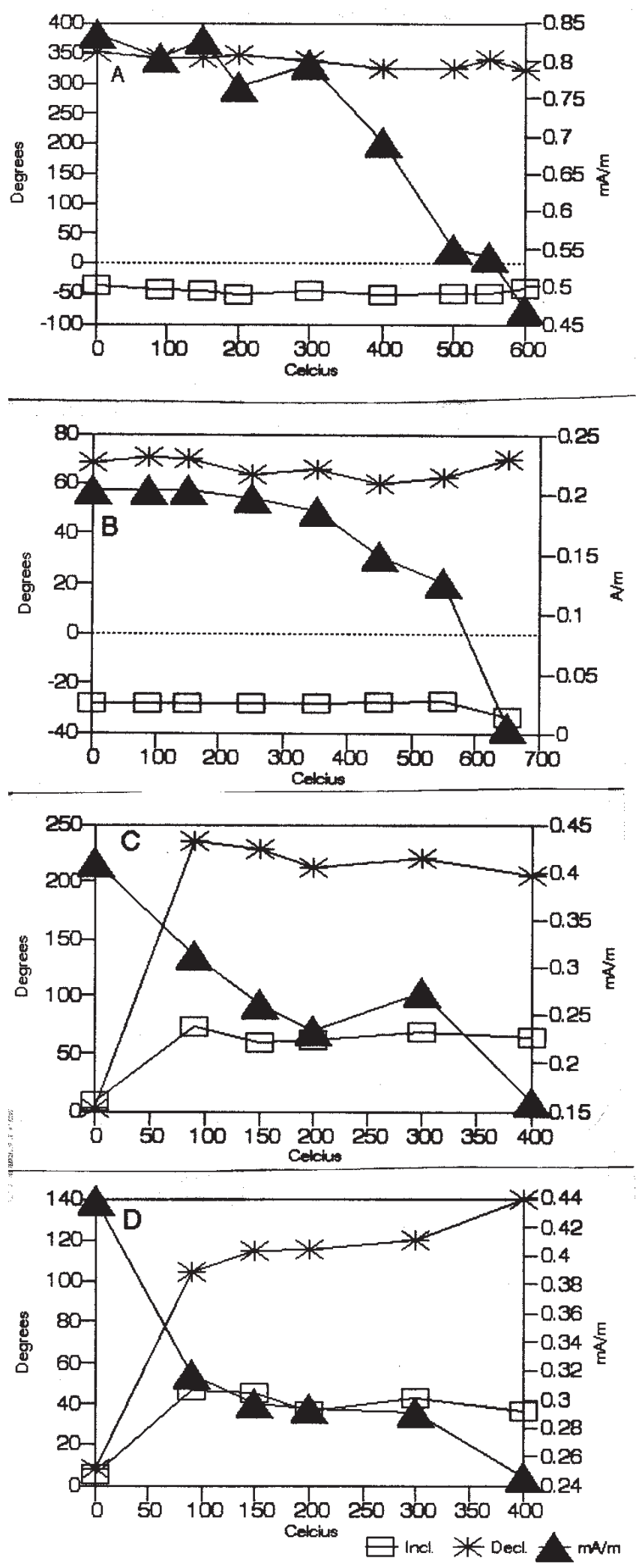

Figure 11. Behaviour of vector length, inclination and declination of paleomagnetic field during demagnetisation of A: Dinosaur nest-bearing limestone of the Lameta Formation, Kheda; B: Inter-trappean sediment at Jejanikua (Kheda); C: Limestone at Kholdoda; D: Limestone at Lametaghat. the inter-trappean sediments at Anjar were powdered, boiled in dilute $\mathrm{HCl}$ followed by $40 \% \mathrm{HF}$ for $10 \mathrm{~min}$ and subsequently cleaned in boiling dilute $\mathrm{HCl}$. This treatment removes opaline material, clay and zeolites but leaves a crystalline fraction. In the crystalline fraction we found bipyramidal, hexagonal quartz which, under the petrographic microscope, showed the presence of glass inclusions (figure 12). The hexagonal crystals are low quarts paramorphs after original high quartz and are well known from other rhyolitic ash beds (Kalb and Klotsch 1941; Yin et al 1992; Bohor and Triplehorn 1993). The presence of the quartz paramorphs is a clear indication of the origin of the clay layers as being rhyolitic bentonites.

Samples of the bentonites were analyzed for their main element composition. The resultant values are shown in table 1 . It is obvious that the material has an extremely high loss by ignition which is caused by a high component of calcite originating from the lake sediment. A standard rhyolite (Best 1982) contains around 1\% CaO. By assuming a $\mathrm{CaO}$ fraction of $1 \%$ and reducing the ignition loss for the carbonate difference we find in both analysis a non-carbonate loss of $3.5 \%$, which we suspect to be zeolite bound water. We normalized the recalculated values against quartz and against a quartz-normalized standard rhyolite (Best 1982). We thereby obtain values of enrichment and depletion as shown in figure 13 .

It has been repeatedly indicated in the literature that Deccan basalt is too depleted in its content of Ir to be responsible for the $50 \mathrm{ng} / \mathrm{cm}^{2}$ Ir found at many marine $\mathrm{K} / \mathrm{T}$ boundaries (Rocchia et al 1988 and refs. therein ). However, we found that flow 2 exposed at Girad had an unusually high content of total carbon (1.800 ppm) and through INA analysis found $1 \mathrm{ppb}$ of Ir. The stratigraphic position of flow 2 at Girad at magnetic susceptibility cycle zero time further supports the possibility of an Ir contribution from the Deccan basalt. The Ir in the basalt represents the degassed end-product and we can only speculate as to the amount released. Assuming a loss of $7 \mathrm{ppb}$ to the atmosphere, it would correspond to $0.8 \%$ of the Deccan pile assuming a volume of 1.5 mill. $\mathrm{km}^{3}$, in order to create a $50 \mathrm{ng} / \mathrm{cm}^{2}$ Ir-richment. The suggested contribution of $7 \mathrm{ppb}$ corresponds to the present amount emitted by the Deccan hot spot at Reunion (Toutain and Meyer 1989).

The sedimentary pulse pattern as shown by the magnetic susceptibility (a pattern representing Milankovich pulses (Hansen et al 1993, 1996, 2000)) allows us to make world-wide correlation of the Lameta beds with sediments of corresponding age from the marine and terrestrial realms. The pulse pattern further renders possible an esti- 


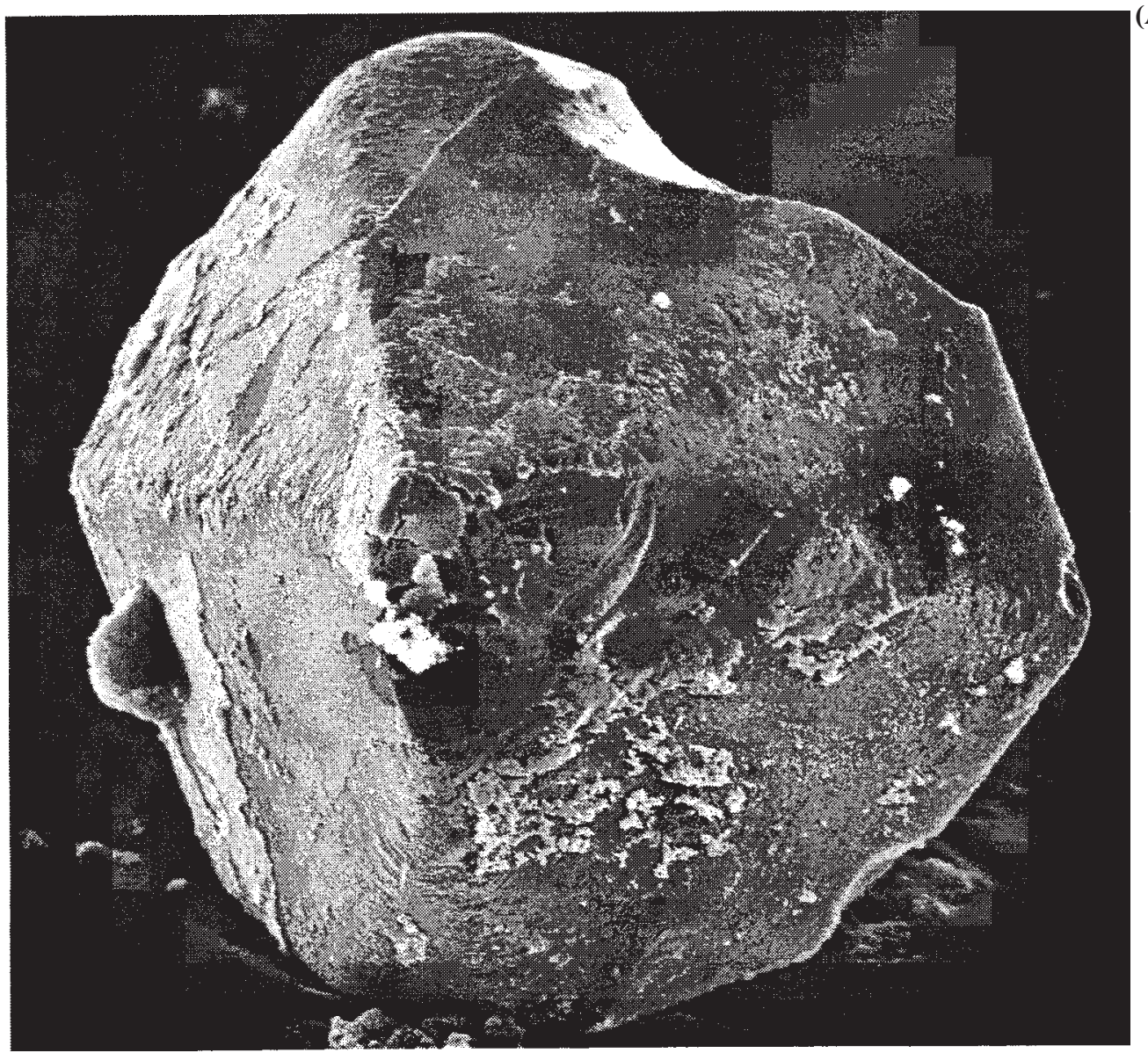

(A)

Figure 12. Bipyramidal hexagonal quartz crystal from the Anjar Ir-bearing rhyolitic bentonite (Ir I/Br III) of the Anjar lake sediments as seen in A: SEM.

mate of the time span in which the sediments were deposited.

The presence of cycle 4 (of Hansen et al 1993, 1996) at Chui Hill demonstrates that the sediments on top of the lowermost crossbedded sand were laid down over a period of 400 to $450 \mathrm{kyr}$. It also permits to give an estimate of the initiation of sedimentation of the Lameta beds exposed south of Nagpur. It seems that they cover a longer time span. However, the time involved for the deposition of the lowermost five meter crossbedded sand at Chui Hill and at Bergi Canal can not be estimated by our method.

\section{Discussion and conclusions}

The inter-trappean lake sediments sandwiched between flow III and flow IV at Anjar contains three Ir-enriched horizons each occurring a short distance below a cm-thick clay bed (Bhandari et al 1995a). The available evidence suggests that flows I-III are of normal magnetic polarity (Bhandari et al 1995b; Courtillot et al 2000), while flows VVII are assigned a reverse polarity. Our measure-
Table 1. Main element analysis of two bentonites from Anjar lake sediments.

\begin{tabular}{|c|c|c|}
\hline Weight\% & Bentonite 1 & Bentonite 2 \\
\hline $\mathrm{SiO}_{2}$ & 43.384 & 29.123 \\
\hline $\mathrm{TiO}_{2}$ & 0.789 & 0.207 \\
\hline $\mathrm{Al}_{2} \mathrm{O}_{3}$ & 4.016 & 0.962 \\
\hline $\mathrm{Fe}_{2} \mathrm{O}_{3}$ & 2.672 & 0.559 \\
\hline $\mathrm{FeO}$ & 0.0 & 0.160 \\
\hline $\mathrm{MnO}$ & 0.042 & 0.088 \\
\hline $\mathrm{MgO}$ & 2.481 & 1.079 \\
\hline $\mathrm{CaO}$ & 22.748 & 34.325 \\
\hline $\mathrm{Na}_{2} \mathrm{O}$ & 0.530 & 0.230 \\
\hline $\mathrm{K}_{2} \mathrm{O}$ & 0.326 & 0.074 \\
\hline $\mathrm{P}_{2} \mathrm{O}_{5}$ & 0.208 & 0.228 \\
\hline Volatiles & 21.370 & 30.518 \\
\hline
\end{tabular}

ments of the polarity of the sediment and flow IV indicate a reversed polarity of both.

In case the $\mathrm{K} / \mathrm{T}$ boundary should be present in the Anjar intertrap it must occur in a reversed interval. Since the underlying basalt flows are of normal polarity, $550 \mathrm{kyr}$ (the Cretaceous part of chron 29R) must either be missing or be represented by ca. $2 \mathrm{~m}$ lake sediments. The underly- 


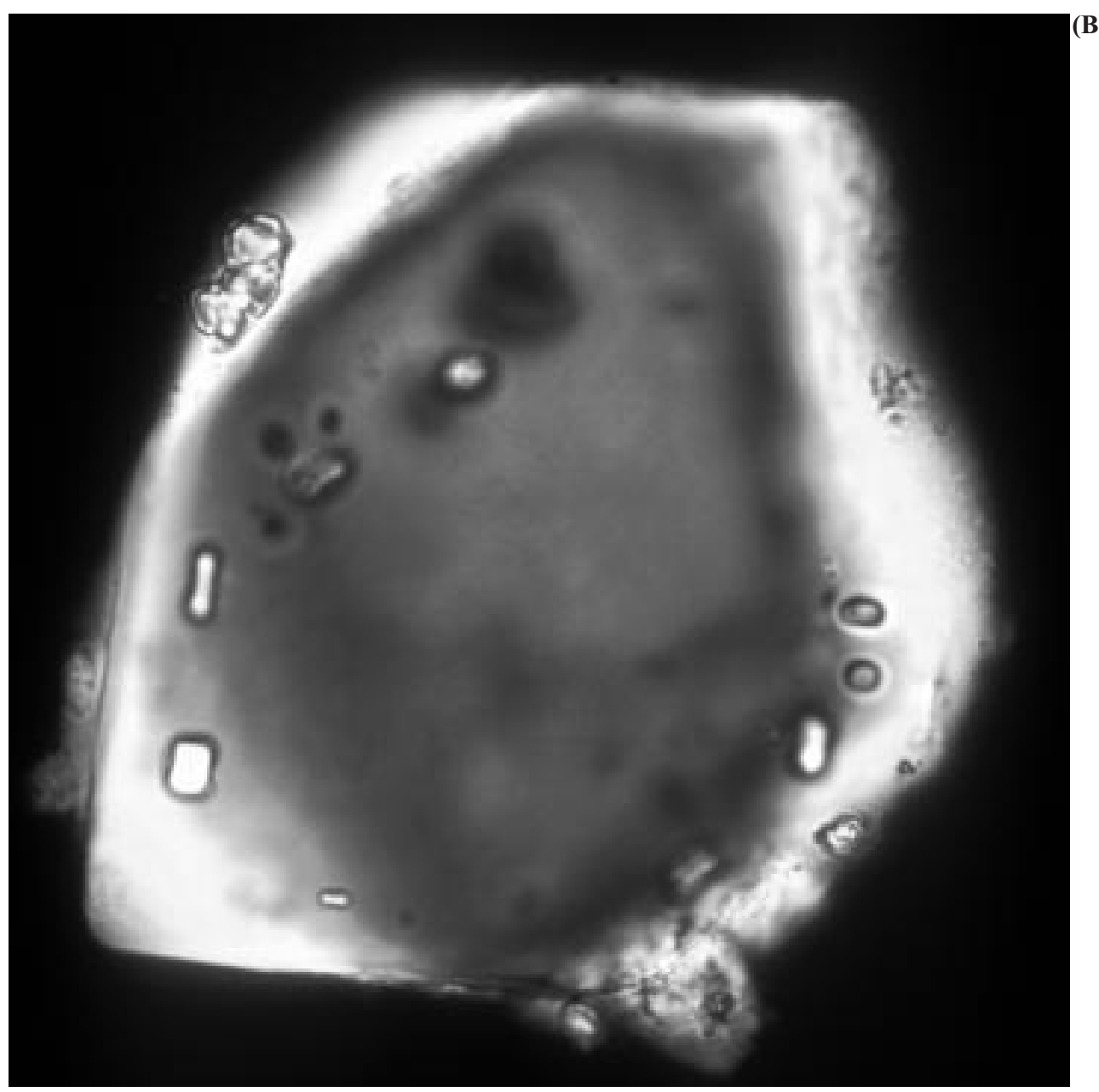

(B)

Figure 12. Bipyramidal hexagonal quartz crystal from the Anjar Ir-bearing rhyolitic bentonite (Ir I/Br III) of the Anjar lake sediments as seen in B: Petrographic microscope. Note glass inclusions.

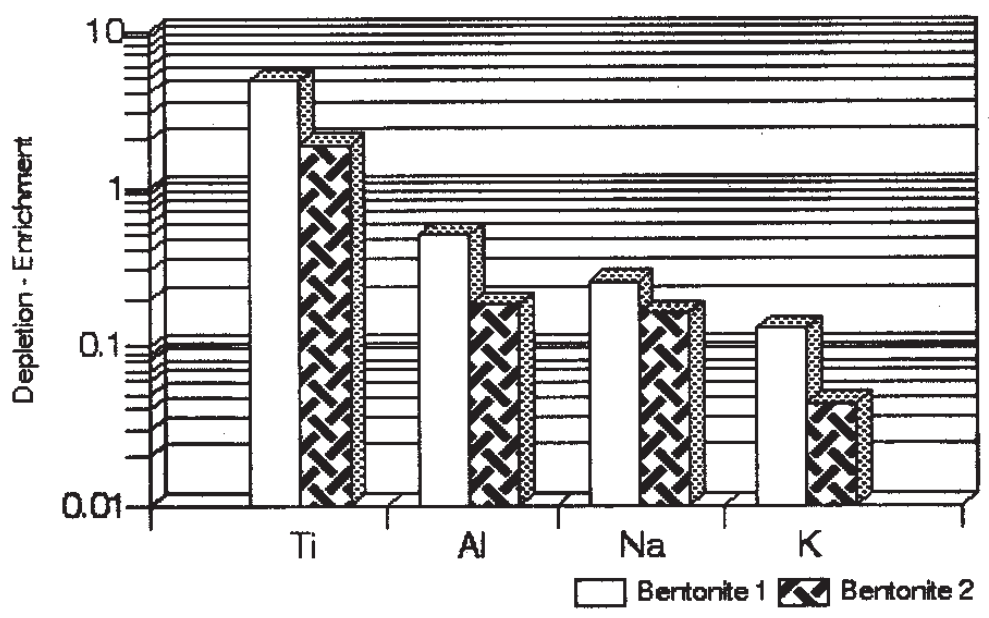

Figure 13. Enrichment and depletion of the main elements $\mathrm{Ti}, \mathrm{Al}, \mathrm{Na}$ and $\mathrm{K}$ of the two leached rhyolitic bentonite layers (Ir I/BrIII and Ir II/BrII) of Anjar lake sediments. 
ing flows must be assumed to belong to chron $30 \mathrm{~N}$ (Courtillot et al 2000).

If we suppose that the time buried in the intertrap sediments between flow III and IV should cover 550kyr, the overlying four flows and their inter-trappeans should have been laid down in about 300 kyr (the Paleocene part of Chron 29R). This can not be excluded as a possibility.

The $\mathrm{K} / \mathrm{T}$ boundary in the boundary stratotype section at El Kef, NW Tunisia, is defined by the disappearance of planktonic foraminifera and coccoliths. At El Kef this level is coincident with an Irenrichment. At other marine boundaries it is not. The definition of the boundary does not encompass an Ir-enrichment. At Anjar each Ir-enriched level is associated with an overlying clay layer, which, for the upper two, can safely be characterized as rhyolitic bentonites, due to the presence of low quartz paramorphs after high quartz with a content of glass-inclusions. It thus seems that a causal relationship between the rhyolitic bentonites and the Ir-enrichments exists at Anjar.

Main element analysis of the two upper bentonites show them to be depleted in $\mathrm{Al}, \mathrm{Na}, \mathrm{K}$, while they are enriched in Ti. This suggests devitrification and leaching of the bentonites and the intimate position of the bentonites with the Ir-levels occurring shortly below, point to the creation of the Ir-enrichments through leaching of the devitrifying bentonites.

The sedimentation pattern as depicted in the magnetic susceptibility of the sediments at Anjar does not reveal a pattern comparable to Lameta profiles such as Chui Hill, Bergi Canal, Kholdoda, Girad and Pisdura. The pattern of magnetic susceptibility of both marine and terrestrial sections around the world (Hansen et al 1993, 1996) is not found at Anjar. The $\mathrm{K} / \mathrm{T}$ boundary is associated with a negative carbon isotopic anomaly. This is not seen in the Anjar section.

The recognition of dinosaur remains raises the question of the reliability of the finds of isolated teeth, bones, eggshell fragments etc. The experience from the $\mathrm{K} / \mathrm{T}$ boundary in Montana, USA, at which redeposited dinosaur remains showing no indication of wear have been found in Paleocene deposits (Rigby et al 1987) suggests great caution before a find is accepted as representing the former presence of dinosaurs. We recognize only three criteria for accepting the former presence of dinosaurs: footprints, eggs in nests and articulated skeletons. By applying these criteria to the occurrences of Indian dinosaurs, the occurrence of nests at Kheda, Chui Hill and Kholdoda (Mohabey 1998), at Sivni Tola (Tandon et al 1998) and skeletal remains at Pisdura (von Huene and Matley 1933; Mohabey and Udhoji 1996) confirms dinosaur presence. The find of an incomplete, but semi-articulated skeleton of Titanosaurus indicus in the lower part of the inter-trappean at Anjar also qualifies. By contrast the isolated bones recovered in the uppermost limestone at Chui Hill do not qualify.

In applying these very conservative and rigourous criteria it appears that the dinosaurs disappeared from India around $300 \mathrm{kyr}$ prior to the $\mathrm{K} / \mathrm{T}$ boundary. This is based on the occurrence of a dinosaur egg clutch $2 \mathrm{~m}$ below the top of the lower limestone at Chui Hill relative to the curve of magnetic susceptibility (Hansen et al 1996) and the corresponding occurrence at Kholdoda at the same level.

Lameta sediments always contain a component of clastic quartz and appear to have their source in the north. By contrast, inter-trappean lake sediments do not contain a clastic quartz component. As the lakes are formed in depressions in the basalt the sediments are of local origin only. Therefore, inter-trappean lake sediments of Lameta age do not have to be subject to the same scrutiny with respect to their fossil content as the Lameta sediments, where redeposition clearly occurs.

The find of dinosaur eggshell fragments and e.g. ostracodes showing no wear above the highest Irenrichment horizon at Anjar speaks against a $\mathrm{K} / \mathrm{T}$ boundary and the presence of an articulated skeleton in the lowermost part of the sequence points to an age older than $300 \mathrm{kyr}$ prior to the $\mathrm{K} / \mathrm{T}$ boundary.

With the exception of Chui Hill, all the Indian $\mathrm{K} / \mathrm{T}$ boundary sections finishes in, what we believe to be, aeolian sediments. Such material naturally contains organic carbon which is not indigenous to the sediment. However, all sections show a development of a negative carbon isotopic anomaly, which returns to more positive values in the aeolian sediment. At Anjar no carbon isotopic anomaly was found and no aeolian sediment is present in the section.

On the basis of these observations we suggest that the Anjar section sediments were deposited early in magnetochron $29 \mathrm{R}$ and are unrelated to the $\mathrm{K} / \mathrm{T}$ boundary.

\section{Acknowledgements}

The findings presented are part of a collaborative work involving Geological Survey of India and Geologisk Institut, University of Copenhagen. The isotopic determinations were made in the Laboratory of Stable Isotopes, Geologisk Institut, the staff of which is thanked for patience and good work. The study was supported by a grant (no. 9503582) from the Danish Natural Science Research Council. We sincerely direct our thanks to the Director 
General, GSI, Calcutta, and the Deputy Director General, GSI, Central Region, Nagpur, for providing the necessary co-operation and help rendered in the course of the joint work. We also owe a debt of gratitude to the geologists of GSI who helped during the field and laboratory work.

\section{References}

Bajpai S 1999 Fossil records from the rich Deccan intertrappean beds, Anjar: Data and inferences. Abstracts p. 1-2, in "Deccan Trap basalts and the K/T boundary"; Phys. Res. Lab, Ahmedabad, India

Bajpai S and Prasad G V R 2000 Cretaceous age for Ir-rich Deccan intertrappean deposits: palaeontological evidence from Anjar, western India; J. Geol. Soc. London $157257-$ 260

Best M G 1982 Igneous and metamorphic petrology; (Freeman and Co.)

Bhandari N, Shukla P N and Pandey J 1987 Iridium enrichment at Cretaceous-Tertiary boundary in Meghalaya; Curr. Sci. 56 1003-1005

Bhandari N, Gupta M, Pandey J and Shukla P N 1994 Chemical profiles in K/T boundary section of Meghalaya India: Cometary, asteroidal or volcanic; Chem. Geol. 113 45-60

Bhandari N, Shukla P N, Ghevariya Z G and Sundaram S M 1995a Impact did not trigger Deccan volcanism: evidence from Anjar K/T boundary intertrappean sediments; Geophys. Res. Lett. 22, 433-436

Bhandari N, Ghevariya Z G and Bajpaj S 1995b K/T boundary problems: Relevance and importance of Anjar intertrappean section. Report on Group and Field workshop Phys. Res. Lab. Ahmedabad, India.

Bhandari N, Shukla P N, Ghevariya Z G and Sundaram S M 1996 K/T boundary layer in Deccan intertrappeans at Anjar, Kutch. In: The Cretaceous-Tertiary Event and other catastrophes in earth history (eds) G Ryder, D Fastovsky, S Gartner; Geol. Soc. Amer. Spec. Pap. 307, 417424

Bohor B F and Triplehorn D M 1993 Tonsteins; altered volcanic ash-layers in coal-bearing sequences; Geol. Soc. Am. Spec. pap. 285, 1-44

Brown G 1980 Associated minerals. In: Crystal structures of clay minerals and their X-ray identification (eds) G. W. Birdley, and G. Brown, Min. Soc. London, 495 p.

Courtillot V, Gallet Y, Rocchia R, Férraud G, Robin E, Hofmann C, Bhandari N, Ghevariya Z G 2000 Cosmic markers, ${ }^{40} \mathrm{Ar} /{ }^{39} \mathrm{Ar}$ dating and paleomagnetism of the KT sections in the Anjar area of the Deccan large igneous province; Earth Planet. Sci. Lett., 182, 137-156

Dolenec T, Pavsic J and Lojen S 1998 Stable isotopes, Ir anomaly and other elemental markers near PalaeoceneEocene transition: evidence from the western Tethys; Miner. Mag. 62A 399-400

Hansen H J, Rasmussen K L, Liu Qingsheng, Benjamini C, Walaszczyk I, Gwozdz R and Stage M 1993 Correlation of marine and terrestrial Upper Cretaceous sediments by their magnetic susceptibility; Bull. Geol. Soc. Denmark 40 175-184

Hansen H J, Toft P, Mohabey D M, Sarkar A 1996 Lameta age: Dating the main pulse of the Deccan Traps volcanism; Gondwana Geol. Mag., Spl Vol. 2, 365-374. (Nagpur, India)
Hansen H J, Lojen S, Toft P, Dolenec T, Tong Jinnan, Michaelsen P and Sarkar A 2000 Magnetic susceptibility and organic carbon isotopes of sediments across some marine and terrestrial Permo-Triassic boundaries; In: Permo-Triassic evolution of Tethys, Circum-Pacific and marginal Gondwana (eds) Yin Hongfu et al. (Elsevier).

Huene F B von and Matley C A 1933 The Cretaceous Saurischia and Ornithischia of central Provinces of India; Palaeontologia Indica, N. S. 21 1-70

Kalb G and Klotsch H 1941 Die Kristalltracht des Hochquarzes in minerogenetischer Betrachtung; Zentralbl. Mineral., Geol., Paleont, Abt. A, 66-72

Kuslys M and Krähenbühl U 1983 Noble metals in Cretaceous/Tertiary sediments from El Kef; Radiochim. Acta 34 139-141

Margolis S V, Swinburne N H M, Alvarez W, McCauley S E, Magde L S, Donovan J, Snyder D, Asaro F, Swisher C C, McWilliams M, Hansen H J and Pedersen A K 1991 Possible impact ejecta in the Paleocene flood basalt province of West Greenland; AGU Fall Meeting, Program and abstracts, $\mathrm{P} 11 \mathrm{~A}-02$

Mohabey D M 1984 Study of dinosaurian eggs from intratrappean limestone in Kheda district, Gujarat; J. Geol. Soc. India 25(6), 329-333

Mohabey D M 1998 Systematics of Indian Upper Cretaceous dinosaur and chelonian eggshells; J. Vert. Pal. 18(2), 348-362

Mohabey D M 2000 Indian Upper Cretaceous (Maestrichtian) dinosaur eggs: their parataxonomy and implications in understanding the nesting behaviour; First International Symposium on Dinosaur Eggs and Babies, extended abstracts, p. 139-153. (Spain.)

Mohabey D M and Udhoji S G 1996 Fauna and flora from Late Cretaceous (Maestrichtian) Lameta sediments associated with Deccan Volcanic episode, Maharashtra: its relevance to the KT boundary problem, palaeoenvironment and palaeogeography; Gond. Geol. Mag. Spl Vol. 2, $349-360$

Rigby J K Jr, Newman K R, Smit J, van der Kaars S, Sloan R E and Rigby J K 1987 Dinosaurs from the Paleocene part of the Hell Creek Formation, McCone County, Montana; Palaios 2, 296-302

Rocchia R, Boclet D, Courtillot V and Jaeger J J 1988 A search for iridium in the Deccan Traps and Inter-traps; Geophys. Res. Lett. $158812-815$

Tandon S K, Andrews J E, Sood A and Mittal S 1998 Shrinkage and sediment supply control on multiple calcrete profile development: a case study from the Maastrichtian of central India; Sedimentary Geology, 119 2545

Toutain J.-P and Meyer G 1989 Iridium-bearing sublimates at a hot-spot volcano (Piton de la Fournaise, Indian Ocean); Geophys. Res. Lett. 16 1391-1394

Venkatesan T R, Pande K and Gopalan $1996{ }^{40} \mathrm{Ar}-{ }^{39} \mathrm{Ar}$ ages of Anjar Traps, western Deccan Province (India) and its relation to the Cretaceous-Tertiary boundary events; Curr. Sci. 70 990-996

Yin Hongfu, Huang Siji, Zhang Kexing, Hansen H J, Yang Fengqing, Ding Meihua and Bie Xianmei 1992 The effects of volcanism on the Permo-Triassic mass extinction in south China p. 146-157. In: Permo-Triassic events in the eastern Tethys (eds) W C Sweet, Zunyi Yang, J. M. Dickins and Yin Hongfu), 181 p., (Cambridge University Press.) 